\title{
Space, Time and Abstract Relations in the Coffin Texts
}

A version of this paper was presented at the International Conference "Language Typology and Egyptian-Coptic Linguistics" held in Leipzig (2-5 October 2008), organized by the Egyptological Institute of the University of Leipzig and the Max Planck Institute for Evolutionary Anthropology.

I propose in this paper some ideas that evolved from the results I reached in my $\mathrm{PhD}$ dissertation on the motion verbs in the Coffin Texts $(\mathrm{CT})^{1}$. These results are based on an exhaustive and systematic analysis of this corpus made with an electronic database from which more than 5,000 cases of study were extracted.

\section{Space: from situation to motion}

It is well known that spatial expressions, beside their specific meaning (situation or motion), may be used to express metaphorically temporal and abstract relations ${ }^{2}$ and that such metaphorical uses may be neurologically based ${ }^{3}$.

1.1. In Egyptian, to express situation the adverbial sentence is used; its structure is: nominal subject $^{4}$ (first participant, $\mathrm{p}_{1}$ ) + adverbial predicate (second participant, $\mathrm{p}_{2}$ ). Spatial possibilities of said expression are:

Gracia Zamacona, C. (2008).

2 In general, cf. Pottier, B. (1962); Hjelmslev, L. (1935 \& 1937); Anderson, J. M. (1976); Lakoff, G./ Johnson, M. (1980), 14, 30-32 \& 41-45; Savary, R. (1984), 16; Langacker, R. W. (1987), 148-149; Rojas Nieto, C. (1988), 23 \& n. 37; Lamiroy, B. (1988); Berthonneau, A. M. (1993); Bertinetto, P. M. (1997), 148 \& n. 18; Haspelmath, M. (1997); Gattis, M. (2001); Naïm, S. (2006). In Egyptian, cf. James, T. G. H. (1962), 111; Winand, J. (2006), 158.

${ }^{3}$ D’Aquili, E. G. (1983), 249, 251, 252 \& 254.

${ }^{4}$ Or equivalent.
- abessive case: the $\mathrm{p}_{1}$ is outside the $\mathrm{p}_{2}$ and faces away from it;

- essive case: the $\mathrm{p}_{1}$ is in the region ${ }^{5}$ of the $\mathrm{p}_{2}$;

- inessive case: the $\mathrm{p}_{1}$ is inside the $\mathrm{p}_{2}$;

- adessive case: the $\mathrm{p}_{1}$ is outside the $\mathrm{p}_{2}$ and it faces it.

Here is an example of the inessive, abessive and adessive cases:

Ex. 1 CT IV 367 c-d

iw db3.w.s $\boldsymbol{m}$ p.t dns.wt.s $\boldsymbol{m}$ t3 qbh.w $\boldsymbol{r}$ p.t $m$ qbh.w z3 $r^{\mathrm{r}} \boldsymbol{r}$ t3 sn.w 3h.t

'Its (= net's) floats (are) in the sky (and) its ballasts (are) in the earth, the fresh waters (are) from the sky, as qbh.w, Re's son, to the earth of misery of the horizon".

The abessive case is very rare. In fact this is the only case I could find in the Coffin Texts and yet the correct interpretation of this example is very difficult. Adessive and inessive cases present no problem.

Finally, here is an example of the essive case:

Ex. 2 CT II 129 b

iw 3.t.k hr ph.wy.k

"Your force (is) on your hindquarters".

It may be graphically resumed in the scheme of Fig. 1.

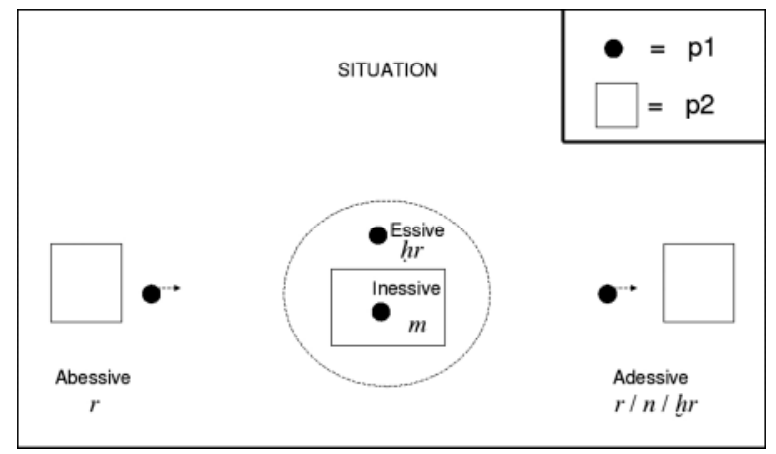

Fig. 1. Spatial expressions.

${ }^{5}$ For the concept, cf. Svorou, S. (1994) \ 2.1.1. 
1.2. When space is expressed within a temporal expression, not only does the syntactical pattern change (from an adverbial sentence to a verbal sentence), but also the semantic content of the expression that is no longer a situation, but a motion (in the broad sense: 'space in time').

The expression of motion is characterized by the presence of a spatial adjunct (SA) as $\mathrm{p}_{2}$ of the motion verb. The SA's semantic structure is as follows:

- if the motion verb expresses displacement (e.g., 'to go'), the SA can indicate provenance, course or destination;

- but, if the motion verb expresses position (e.g., 'to stand'), the only possible SA is a locative.

Each of these cases can be interior, exterior or general, which leads us to the two possibilities of Figs. 2 and 3.

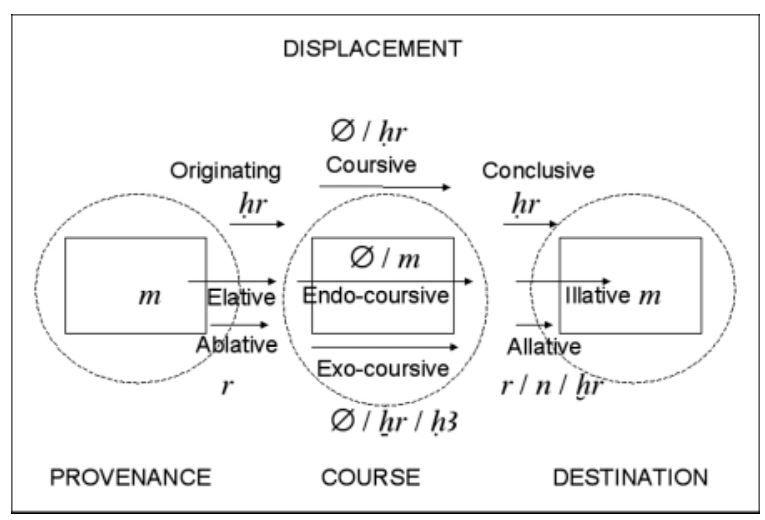

Fig. 2. Expression of displacement.

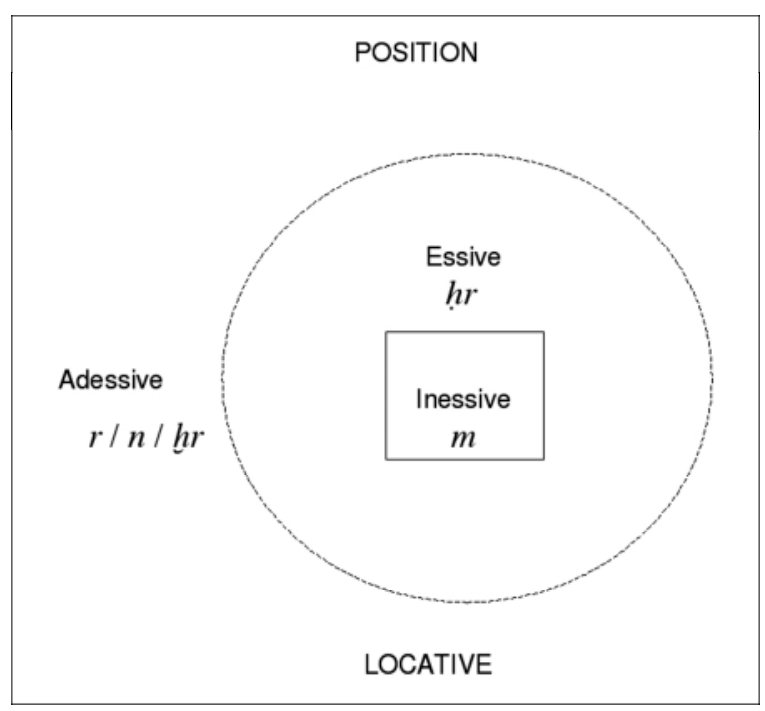

Fig. 3. Expression of position.
There are entities in Egyptian that, as they are introduced by prepositions, seem to be conceived as possessing internal space. These entities accept the opposition between the preposition $m$, that expresses the feature 'interior', and $r$, that expresses the feature 'exterior'. Other entities lack internal space and do not accept that opposition: the neutralisation of this opposition is expressed by the preposition $h r$, which has the feature 'general' (i.e. not interior nor exterior). Egyptian simple prepositions express these basic features, but not the features 'provenance', 'course' or 'destination', that depend on the verb and the context.

In order to describe the basic spatial meanings of Egyptian prepositions other features are (prototypically) $^{6}$ required. These are 'animate/ inanimate', 'divine/non-divine' and 'limit/nonlimit'. This is the resulting table:

Table 1

\begin{tabular}{|l|l|l|l|l|}
\hline Prepos. & $\begin{array}{l}\text { Interior } \\
\text { space }\end{array}$ & Limit & Animacy & Divinity \\
\hline$h r$ & - & - & - & - \\
\hline$m$ & + & - & - & - \\
\hline$r$ & + & + & - & - \\
\hline$n$ & + & + & + & - \\
\hline$h r$ & + & + & + & + \\
\hline
\end{tabular}

Just to illustrate the SAs of displacement verbs, here is an example of the cases with the feature 'interior' (illative, elative and endocoursive):

Ex. 3 CT II 38 c

pr min $\boldsymbol{m}$ imn.tt $\boldsymbol{m}$ i3b.tt $\boldsymbol{m}$ h.t n.t $n$ w.t

"Go up today into the West from the East, through Nut's belly!"

And to illustrate the SAs of position verbs, here is an example of adessive and inessive cases:

Ex. 4 CT VII $231 \mathrm{~b}$

hmm.f wr r psd.t hms $\boldsymbol{m}$-h̆nt wrr.w $\boldsymbol{m}$ iwnw

"hmm.f, greater than the Ennead! Sit down in front of the Great Ones in Heliopolis!"

${ }^{6}$ The concept is well exposed in Kleiber, G. (1990). 
Let us see now the semantic extensions of the spatial prepositions: firstly, the temporal ones, then the abstract relations.

\section{$\$ 2$. From space to time}

Temporal semantic extensions of spatial expressions (situation and motion) are expressed by pseudoverbal constructions with infinitive, and by circumstantial (temporal) clauses.

In figure 4 there is a scheme of these temporal extensions.

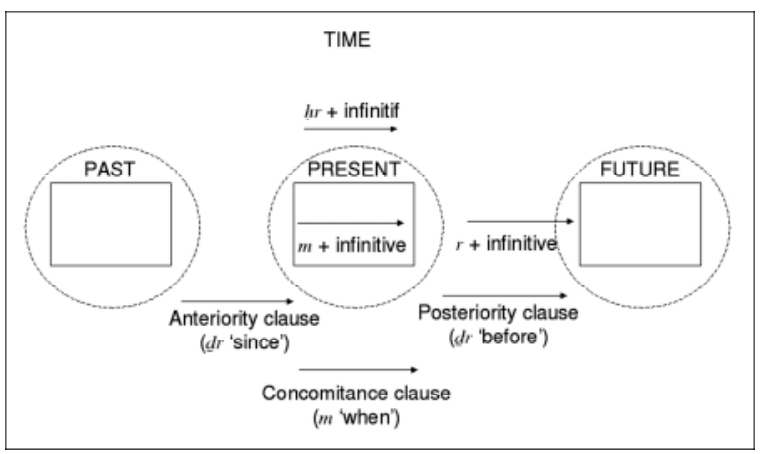

Fig. 4. Temporal semantic extensions.

2.1. Among the temporal semantic extensions, the pseudoverbal constructions with infinitive are fundamental. These constructions are formally adverbial sentences ${ }^{7}$. Notwithstanding this, the prepositions keep their basic meaning: $m$ indicates an action as an entity with interior space, $h r$ indicates an action as an entity without interior space, while $r$ indicates an action at its "right" limit, graphically speaking: in fig. 4, past is at the left and future at the right.

All three of these constructions are imperfective, which comes, in general, from their original formal nature (adverbial sentence). But the specific temporal effets de sens come from the semantic values of the prepositions and the entities (in this case infinitives) introduced by them.

The opposition $m / h r$ for the imperfective non-future and non-general ${ }^{8}$ would originally be

\footnotetext{
I am speaking about form, not about functions here. Cf. Junge, F. (1970).

${ }^{8}$ Vernus, P. (1990), chap. 8.
}

based on the opposition between essive and inessive cases of situations' (cf. 1.1) and between interior space and absence of interior space of the SAs (cf. 1.2). A punctual state-of-affairs could be conceived as having no interior temporal space (i.e. duration) $)^{10}$, while a non-punctual state-of-affairs would appear to have interior space. So, it would be the semantic extension of a spatial concept into the temporal domain (more precisely, into the verbal Aktionsart). Consequently, non-punctual dynamic verbs would naturally accept the $m+$ infinitive construction to express the progressive, while with achievements without a prephase, this construction would take an imminent sense ('to be about to do something' $)^{11}$. As for the $h r+$ infinitive construction, it would naturally be accepted by punctual states-of-affairs to express the progressive. Nevertheless, this construction seems to be grammaticalized for the progressive of all statesof-affairs since it appears in the texts known at the present time ${ }^{12}$.

I present here some arguments regarding these constructions in the Coffin Texts, depending on the Aktionsart of the verbs concerned.

Firstly, the verbs with reduplicated root (e.g., 1212) are activities with an iterative effet de sens $(<\ldots>)$ because the lexical base of these verbs is punctual, either an achievement $(<+>)$ or a semelfactive $(<.>)^{13}$. So, the progressive of verbs with a reduplicated root is expressed by the $m+$ infinitive construction and not by the $h r+$ infinitive construction, as shown in table 2:

Ex. 5 CT VI $86 \mathrm{~g}$

iw.i $\boldsymbol{m}$ h h h h.tyw.i

"I am looking for my enemies".

\footnotetext{
9 For the morphological relationship between progressive and essive and inessive cases, cf. Traugott, E. C. (1978) \2.3.1; Traugott, E. C./König, E. (1991), 207; Bertinetto, P. M. (1997), 80 (inessive).

${ }^{10}$ Klein, W. (1994), 186-187 \& 195.

${ }_{11}^{11}$ Winand, J. (2006), 310.

12 Vernus, P. (1990), 158-162; Collier, M. (1994), 60-67; Vernus, P. (1996), 66-75; Winand, J. (2006), 306.

${ }^{13}$ For these symbols, cf. Malaise, M./Winand, J.

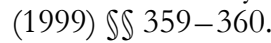


Table 2

\begin{tabular}{|c|c|c|c|}
\hline \multirow[t]{2}{*}{ Verb } & \multicolumn{2}{|c|}{$m+$ infinitive } & \multirow{2}{*}{$\begin{array}{l}h r+\text { infinitive } \\
\text { Progressive }\end{array}$} \\
\hline & Imminent & Progressive & \\
\hline « 'shake' & - & $1^{14}$ & - \\
\hline $\begin{array}{l}h \stackrel{h}{h} \\
(<h w w i h w i) \\
\text { 'look for' }\end{array}$ & - & $5^{15}$ & - \\
\hline
\end{tabular}

Secondly, as it was said above, with achievements lacking a prephase $(<+\rangle \_$and $<+>$.....), the $m+$ infinitive construction adopts an imminent effet de sens, while the progressive is expressed by the $h r+$ infinitive construction, as we can see in table 3 .

Table 3

\begin{tabular}{|c|c|c|c|}
\hline \multirow[t]{2}{*}{ Verb } & \multicolumn{2}{|c|}{$m+$ infinitive } & \multirow{2}{*}{$\begin{array}{l}h r+\text { infinitive } \\
\text { Progressive }\end{array}$} \\
\hline & Imminent & Progressive & \\
\hline $\begin{array}{l}b \underline{t} i \\
\text { 'forsake }\end{array}$ & $1^{17}$ & - & - \\
\hline $\begin{array}{l}\text { pri } \\
\text { 'go out, } \\
\text { go up' }\end{array}$ & $1^{18}$ & - & - \\
\hline rdi 'put' & $1^{19}$ & - & - \\
\hline $\begin{array}{l}\text { h3i 'go } \\
\text { down' }\end{array}$ & - & - & $1^{20}$ \\
\hline ḩbs 'cover' & $1^{21}$ & - & - \\
\hline
\end{tabular}

Ex. 6 CT VII 52 a-c

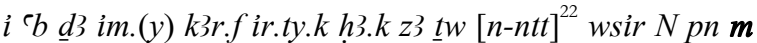
pr.t $m$ htp.w.fipn r.k $\underline{d} b .(w)$

"Oh horn who have ferried, who are in your chapel! Look backwards (lit. your eyes behind you)! Beware [because] this Osiris $\mathrm{N}$ is about to go out with these offerings of his (and) your mouth is blocked!'

${ }^{14}$ CT V $40 \mathrm{c}$.

${ }^{15}$ CT II 111 i, IV 174 f, IV 182 n, V 284 b \& VI 86 g.

${ }^{16} \mathrm{~Wb} \mathrm{I}, 485(b t)$. For classifying this verb as a III ${ }^{\mathrm{a}}$ inf., cf. CT V $332 \mathrm{~g}$ (bt.y.f prospective).

${ }^{17}$ CT VI $293 \mathrm{~d}$

${ }^{18}$ CT VII 52 b.

${ }^{19}$ CT VI $193 \mathrm{c}$

${ }^{20}$ CT IV 345 a.

${ }^{21}$ CT VI 193 c.

${ }^{22}$ This restauration is hypothetical.
Ex. 7 CT IV 344 c-345 b

wn n.i sb3.w imh.t $r$ w3.wt nfr. (w)t $m$ hrw tp-m iw nsrsr $n$ m3.tyw r bw n.ty 3h.tyw im pr.i im hr sb3 dsr i33 nfr hr smi.t.i n.tn $m$ wỉ $n$ hpr-ds.f ir.yw him.w hr h3.(t) ${ }^{23} r i t 3$ sšm.w hr $m d w . t n$ m3`.t

"Open for me the doors of the Afterworld to the beautiful ways by day, towards the Island of the Flame of the Righteous Ones, to the place where the Spiritualized Ones (are), that I may go up there through the sacred door, the beautiful $i 33$ informing you about me in the Self-created's wi3-bark, the guardians of the steering-oars going down to earth (and) the guides talking to Maat!'

Another fact showing this semantic extension could be the expression 'to retract' $(h m i)+m /$ $* h r+$ abstract name/infinitive, where nonpunctual states-of-affairs would be indicated by $m$ (elative). Unfortunately, there is no occurrence for $h r$ (originating case).

Ex. 8 CT V 322 k-m

ht.t(i) $\mathbf{h m} . t(\boldsymbol{i}) n$ tz.wy ipwy dd.n 3s.t r.k $\boldsymbol{m}$ iw.t.k $r$ wd.t sh 3 $m r n$ wsir $n$ ib $n$ sth h hf.t(y).f $m \underline{d} d . s r . k$

"Now you have gone back, now" ${ }^{24}$ you have retracted, because of these two sentences Isis has spoken against you, from coming to put memory into Osiris' mouth due to Seth's desire, his enemy, according to what she (= Isis) says to you".

As for the imperfective future $r+$ infinitive construction $^{25}$, the preposition $r$ indicates a limit "by the right", i.e. the adessive and allative $\operatorname{cases}^{26}$ (cf. 1.1), existing also at other levels ${ }^{27}$, and the verbal form (infinitive) puts the state-of-

${ }^{23}$ Faulkner, R. O. (1994-1996), I, 275 \& n. 7 (CT [341]) considers it an old perfective with $h r$ 'face' as its subject. Carrier, C. (2004), I, 850-851 translates it as if it were $h r+$ infinitive, but transliterating $h$.

${ }^{24}$ These old perfectives are usually translated as imperatives. In fact, the compelling effet de sens is a consequence of the old perfective selection of the static postphase of these state-of-affairs, possibly accomplishments, what I have tried to translate using 'now' before the present perfect. Perhaps one could paraphrase it with 'You find yourself in the state of having retracted from'.

${ }^{25}$ Vernus, P. (1990), chap. 1. This construction opposes the prospective, which is a perfective future: cf. Loprieno, A. (1986).

${ }^{26}$ For the relationship between the allative case and the future, a well known phenomenon in general linguistics, cf. Traugott, E. C. (1978), 376.

${ }^{27}$ The SAs (cf. 1.2), final clauses (cf. 3.2.3), opposition (cf. 3.2.4), comparison (cf. 3.3.5) and the $r$ of future (cf. 3.3.2). 
affairs in the time. This is an example from the Coffin Texts:

\section{Ex. 9 CT IV $89 \mathrm{~g}$}

iw.i $\boldsymbol{r} \boldsymbol{w b 3}$ n.k w3.wt imh.t

"I am going to pierce for you the ways of the Beyond".

The semantic continuity between the adessive case and this future construction, both formally adverbial sentences, is explicit in the following example. In this example, the deceased answers with the structure in question to the goddess h3ni.t who uses an adverbial sentence. The context is the ferryboat demand:

Ex. 10 CT VI 338 q-r

$-i(w) \cdot k r . k \boldsymbol{r} z b \cdot w(=z y)^{28}$

"You are then (bound) to what? $(\simeq$ What are you going to do ?)"

- iw.i $\boldsymbol{r} d w 3 r^{\mathrm{c}}$

"I am to adore $\operatorname{Re}(\simeq$ I am going to adore $R e) "$

This semantic extension implies a linear vision of time developing from past to future. In other words, the vision of time according to the orientation of the entities (the subject, par excellence) in time ${ }^{29}$. In fact, this vision of time comes from a more general notion, facing ${ }^{30}$, which justifies the future value of this construction: as the temporal fluid flows from past to future, the subject shows the face to the future, which is linguistically expressed by the construction under study. Concerning this, one should note the expression $\check{s} m+$ subject $+m-s 3 h r+$ possessive suffix (= subject) 'go after his/her face', i.e. 'go ahead $^{31}$.

As a matter of fact, time may also be conceived in the contrary sense, from the point of view of time itself, flowing from future to past, but this does not seem relevant to our study ${ }^{32}$.

${ }^{28}$ Following Faulkner, R. O. (1994-1996), II, n. 11 (p. 267).

29 Rojas Nieto, C. (1988), 110.

${ }^{30}$ Kimball, J. (1974); Fillmore, Ch. J. (1975), 49; Lyons, J. (1994), 691; Lakoff, G./Johnson, M. (1980), 14 \& 41-45; Rojas Nieto, C. (1988), 76.

${ }^{31}$ CT VII 477 e-f. Faulkner, R. O. (1994-1996), III, p. 171 \& n. 6 (CT [1134]).

Lyons, J. (1994), 698; Rojas Nieto, C. (1988), 108-109; Bertinetto, P. M. (1997), 146 (n. 15). For this double concept of the future also in English, cf. Lakoff, G./Johnson, M. (1980), 41-43. Cf. also the
2.2. Other temporal extensions are the temporal clauses.

The preposition $\underline{d} r$, indicating theoretically the limit "by the left" in the abessive case, has not produced the same temporal effect as the preceding construction.

In fact, the construction $\underline{d} r+$ verbal form is a clause of anterior time. Nevertheless, this preposition keeps the idea of limit "by the left", hence the meaning 'since'; placed at a superior syntactical level, $\underline{d} r$ is used as a conjunction. For instance,

Ex. 11 CT I $141 \mathrm{~d}-\mathrm{e}$

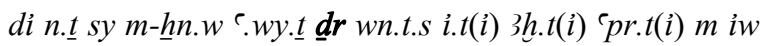
nsrsr

"Put her then inside your hands as soon as she will be come, spiritualized (and) equipped from the Island of the Flame!"

But this construction can also mean 'before', which implies, on the contrary, a limit "by the right": so, it is also used for clauses of posterior time. For instance,

\section{Ex. 12 CT I $242 \mathrm{f}$}

my $m$ rm.n wsir $N$ pn $\underline{d}$ r hr.t.fir.n

"Come then! May we cry (for) this Osiris $\mathrm{N}$ before he is far from us!"

This could be explained by the use of specific verbal forms or by the etymology of this preposition, $d r .(w)$ 'limit" ${ }^{33}$ (so, indifferently usable for both points of reference), or by both facts together ${ }^{34}$. It should be noted that the subordinate clause with $\underline{d} r$ has also a causal meaning: it is an extension derived from the semantic temporal extension that will be studied in 3.1.1. As an example,

\section{Ex. 13 CT VII $353 \mathrm{a}^{35}$}

stt.n.f $\underline{\boldsymbol{d}} \boldsymbol{r}$ hr.fim.f

"It is because it (= Osiris' fluid) has fallen there (= Rostau) that it (= Rostau) has isolated (itself)".

Hebrew root $q d m$ 'in front', 'east', 'ahead', 'advance', 'antiquity', 'origin'.

${ }^{33}$ Cf. the composed preposition $m-\underline{d} r .(w)$ : Edel, E.

(1954-1964) § 812; Junge, F. (1996), 242-243.

${ }^{34}$ Cf. Depuydt, L. (1998), section II.

${ }^{35}$ Main version. 
The value 'internal space' for the preposition $m$, extended on the temporal plan, allows this preposition to introduce, as a conjunction, clauses of concomitant time.

\section{S3. From space to abstract relations}

Beside the temporal semantic extensions, prepositions expressing space have other semantic extensions expressing abstract relations such as opposition, comparison or identity. These abstract semantic extensions can be explained, like the temporal semantic extensions, by the meaning of the prepositions in the adverbial sentences.

The abstract semantic extensions are classified in three categories: cause (where the first participant is placed with regard to a limit "by the left"), finality (where the first participant is placed with regard to a limit "by the right") and characterization (where the first participant is placed in a situation without limits or with regard to a limit "by the right", having in this latter case a future or modal meaning), compare Fig. 5.

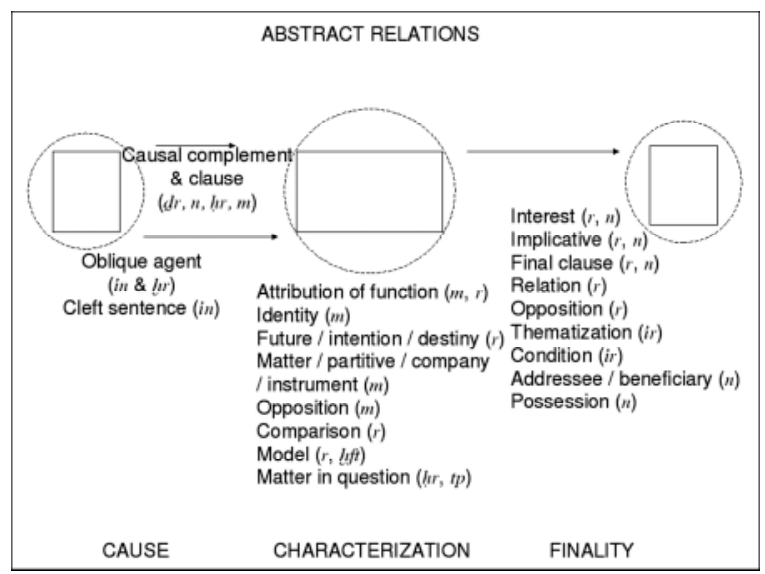

Fig. 5. Abstract semantic extensions.

\subsection{Cause.}

3.1.1. Causal adjuncts and clauses.

The notional semantic extension of cause we have mentioned in $\mathbf{2 . 2}$ for the preposition/conjunction $\underline{d} r$ is also documented for the prepositions $n, h r$ and $m$, which introduce causal ad- juncts and clauses. The use of the preposition $n$ for this meaning presents no problem, since it has the feature 'limit'. As for the prepositions $h r$ and $m$, their use to express cause must come from their use to indicate the local function of provenance for the SAs (cf. 1.2). Here is an example:

Ex. 14 CT VI $220 \mathrm{u}$ $n f^{\tau} . n . i$ m'nd.t hr ir.ty. $k$ hrr

"It is because of your eyes, Horus, that I have pushed back the day-bark".

\subsubsection{Oblique expression of the agent.}

Oblique expression of the agent (typically animate), usually indicated by in, but sometimes also by $h r^{36}$, shows the non-divine/divine opposition among animates, as we have already seen for their spatial functions (cf. 1.2).

In the Coffin Texts, this opposition seems to be about to disappear in favour of in: in seems to introduce any kind of oblique agent, but, in some cases, different documents hesitate (even within a single document) between these two prepositions, when the agent is divine.

Ex. 15 CT II 389 b

rdi.n.t(w) nn n $\underline{t} 3 w . w n N p n \boldsymbol{i n}^{37} / h^{38} n n n h w n . w t$

"It is for this $\mathrm{N}$ that these winds have been given by these ladies".

If $i n^{39}$ were etymologically related to $n^{40}$ and if it also had the feature 'limit' (as do $h r, r$ and $\underline{d} r$ ), we would have here two morphemes able to express, at the same or at different syntactical levels, the limits by the "left" and by the "right"

${ }^{36}$ Edel, E. (1954-1964) \ 768 (f).

${ }^{37} \mathrm{BH} 1 \mathrm{Ox}, \mathrm{G} 1 \mathrm{~T} \& \mathrm{~A} 1 \mathrm{C}$.

${ }^{38} \mathrm{~B} 1 \mathrm{Bo}, \mathrm{S} 2 \mathrm{C}, \mathrm{B} 6 \mathrm{C}, \mathrm{B} 2 \mathrm{Bo}, \mathrm{B} 4 \mathrm{Bo}, \mathrm{Y} 1 \mathrm{C}, \mathrm{M} 22 \mathrm{C}$, $\mathrm{BH} 2 \mathrm{C} \& \mathrm{~T} 3 \mathrm{C}$.

${ }^{39}$ For the syntax of in, see Loprieno, A. (1988); Loprieno, A. (1995), 64-65, 83-84 \& 100 (mainly); Reintges, Ch. (1998).

${ }^{40}$ Possible writing in for $n$ (beneficiary) in CT VI $254 \mathrm{e}-\mathrm{f}$ (B3Bo): $i$ h3b in $n b w^{r}$ mr.t $r^{r}$ "Oh, send for the Unique Master what Re wishes!"

${ }^{41}$ The latter seems to be the "marked term" of the pair: cf. for instance Delancey, S. (1982), 170 (\& n. 12) \& 179; Lazard, G. (1994), 226. Cf. also Vandeloise, C. (1988), n. 13 (p. 109). 
action can be considered as a continuum flowing between two points whose marks can be, in a sense, symmetrical. We can formulate the hypothesis that such a symmetry was expressed by a different vocalisation, even if this is difficult to demonstrate. In Burmese, for instance, the morpheme ko indicates patient and destination, while the morpheme ká indicates provenance and agent ${ }^{42}$.

It is in the sense of the symmetry of marks that the causal clause introduced by $n$, already mentioned, as well as the cleft sentence introduced by in should be considered.

\subsection{Finality.}

\subsubsection{Interest.}

The preposition $r$ indicating inanimate allative, and its equivalent $n$ for the animate allative, shows also a notional extension for expressing interest. Two examples:

Ex. 16 CT I $299 \mathrm{~m}$

$r s \boldsymbol{r}$ t.k pn srfirí. (w).n.i n.k

"Wake up for this cooked bread that I have made for you!"

Ex. 17 CT I $205 \mathrm{f}$

sd? n.k 3h.t mi r $r^{c}$

"The horizon has quivered for you as (it does for) Re".

\subsubsection{Implicative.}

These two prepositions $(r$ and $n)$ appear also to indicate the implicative, typically after the imperative and similar tenses. For example,

\section{Ex. 18 CT V $74 \mathrm{v}$}

ini n.i r.k wrs.s

"So, bring me its (= boat's) mast support!"

\subsubsection{Final clauses.}

This is also the reason why the preposition $r$ is used as a conjunction to introduce final clau-

\footnotetext{
${ }^{42}$ Lazard, G. (1994), 117.
}

ses. More rarely, the preposition $n$ can express finality too, for example:

Ex. 19 CT VI $310 \mathrm{k}-1$

p3.n.f itt.n.f $m$ bik pw 3 hr. (y) znb.w ḥw.t imn rn.f ịti hrr.t $n . t(y)$ w im $\boldsymbol{n}$ dsr p.tr $t 3$ nw.w

"It is just like that great falcon that (is) on the battlements of the mansion of the one whose name is hidden, the one who has taken what belongs to those who (are) there to separate the sky from the earth (and from) Nun, that he has flown off (and) fluttered".

\subsubsection{Relation, opposition, thematization and condition.}

For a similar reason, the preposition $r$ expresses the simple relation, opposition (cf. 3.3.4), thematization (ir form) and condition (ir form). This is an example of the relation use:

Ex. 20 C'T V 150 a

h.t nb.t smh.t.n.i $m$ mhn.t th nis.t.n.i r.s

"Everything I have forgotten on this ferry (is) what I had invoked with regard to it".

\subsubsection{Addressee/beneficiary.}

The same goes for the addressee/beneficiary (indirect object), that can be considered as an extension from the animate allative, both functions indicated by the preposition $n$. The indirect object, typically animate, human and determined frequently appears in the destination space. With transfer verbs (e.g. ini), which are trivalential actions, the adjunct introduced by $n$ is typically the indirect object, but with other verbs, the analysis is more complex. For instance, with a displacement verb, it is difficult to decide between an allative and an addressee/ beneficiary.

Ex. 21 CT VI $157 \mathrm{~h}$

šm.n n.f zb.wn k3.sn $m$ h hִ

"It is for him that have gone those who have departed in joy for their $k$ "'.

\footnotetext{
${ }^{43}$ For some (rare) probable cases with inanimate, cf. for instance CT V 290 k; VI 2 g. Cf. also Posener, G. (1956), 156-157 (Golénischeff, W. (1913), 25 \& pl. $\mathrm{XV}$, 1l. 57-58), although it is about inhabited places; James, T. G. H. (1962), 41.
} 


\subsubsection{Possession.}

In adverbial sentences, as well as in prepositional phrases, the preposition $n$ can express possession, an extension from animate adessive, where both participants are at different levels (possessor and possessed).

Ex. 22 CT II 170 e

iw $h w$-ib-tzm $\boldsymbol{n} r^{c}$

"The sceptre Authority-of-dog's-heart (is) for Re".

This kind of permanent possession, expressed by possessed $+n+$ animate possessor, must be clearly distinguished from contingent possession that is expressed by the structure possessor $+\underline{h} r+$ inanimate possessed. In fact, the latter is an extension of the adessive meaning of the preposition $\underline{h r}$ ' under $^{44}$. We may find a paraphrase of it in the expression smn + object $+\underline{h} r+\mathrm{X}$ (owner) $=$ "put + object + under the ownership of X'"

Ex. 23 CT VI $340 \mathrm{~g}$

in gb smn $\mathbf{s}(\boldsymbol{y}) \underline{h}$ r.i ' q.i pr.i im.s nhnh.w.

"It is Geb the one who placed it (= the abode) under my (ownership) to go in (and) out of it in joy".

\subsection{Characterization.}

\subsubsection{Attribution of function.}

As Vernus has already remarked ${ }^{45}$, the expression $r d i+$ object (person) $+m / r+$ rank is used to indicate the attribution of a function to a person, in different ways depending on the preposition. This expression displays another semantic extension of the prepositions $m$ and $r$ in which their basic opposition reappears: if the attributed function is at the same level as the old function (which constitutes the reference space), the preposition $m$ is used; on the other hand, if the "displacement" from one function to the other implies a hierarchical change, the preposition $r$ is then employed.

\footnotetext{
${ }^{44}$ Malaise, M./Winand, J. (1999) \ 241.

${ }^{45}$ Vernus, P. (1997), 73 (n. 205); Vernus, P. (1999), 104.
}

Ex. 24 CT VI $310 \mathrm{e}-\mathrm{f}$ rdi.n $N$ pn rs.w $\boldsymbol{r}$ 3tw.t.f iw mh.yt $\boldsymbol{r}$ mn $. t . f$

"That this $\mathrm{N}$ has put the southern wind as his 3tw.tnurse is when the northern wind is as his $m n^{e} . t$ nurse".

For the second case, the Coffin Texts provide similar expressions of the dead's promotion to a superior rank:

- The excellence: $z b i \vec{i}+r+i m 3 h$ 'pass to excellence (state)', always with $r$ :

Ex. 25 CT VII 331 b

$\boldsymbol{z} \boldsymbol{b} N$ th $\boldsymbol{r} \boldsymbol{i m} 3 \boldsymbol{h}$ mi $\boldsymbol{r}^{\mathrm{r}} \boldsymbol{r}^{\mathrm{C}} \mathrm{nb}$

"May this $\mathrm{N}$ pass to excellence as Re (does) every day!"

This very rank $(i m 3 h)$ can also be received $(\check{s} z p)$ by the dead:

\section{Ex. 26 CT VI $126 \mathrm{~h}$}

iw szp.n.i im3h.i hr pth-skr

"I have received my excellence from (lit. by) PtahSokar".

- The status of a goddess' scribe: $t n i$ (in passive $)+$ patient subject $+r+$ function $(z \bar{s} . s)$ 'to be promoted to the function of her (= goddess') scribe’:

Ex. 27 CT VI $135 \mathrm{~m}-\mathrm{n}$

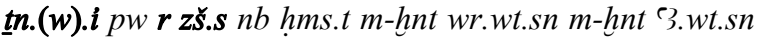
hm.wt.sn ist

"It (means that) I have been promoted to (the function of) her (= Hathor's) scribe, possessor of a seat at the head of their Great Ones (wr.t), their Highest Ones (3.t) and their women".

- The sky: $\check{s} d i / r d i$ (in passive) + patient subject $+r+$ p.t ( + final clause) 'to be pulled/put to the sky (to perform a function)':

Ex. 28 CT V 159 d-f

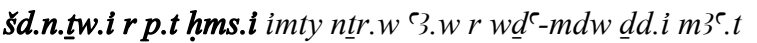
"That I have been pulled up to the sky is for me to sit among (lit. between) the great ( 3 ) gods to judge, to say the truth".

It is interesting to recall that with the verb iri, an accomplishment, the opposition seems to be neutralized in favour of $m$ :

Ex. 29 CT VI $290 \mathrm{a}-\mathrm{b}$

[...] iri.n.f sw $\boldsymbol{m}$ nb sh.t htp.w $r^{\mathrm{e}}$ is hr sn.wt [...]

"[...] (and) he (= the deceased) has made himself as Master of the Field of Offerings like Re, possessing the sn.t-loaves: [...]". 


\subsubsection{Identity and future/intention/destiny.}

The relation of the uses of the above mentioned prepositions with two particular uses in the context of the adverbial sentence must be stressed: the preposition $m$ expressing identity ${ }^{46}$ and the preposition $r$ indicating future, intention or destiny ${ }^{47}$. These are semantic extensions of the inessive and adessive, respectively:

\section{Ex. 30 CT II 113 f}

iw hd-wr $\boldsymbol{m}$ nht.i [...]

"The Great-Bright (is) as my power [...]".

Ex. 31 CT III 313 c

ink wsir iw.i $\boldsymbol{r} 3 b d . w$

"I am Osiris: I (am bound) for Abydos".

As for the $m$ of identity, the second participant is generally ${ }^{48}$ at the same level of individuation $^{49}$ as the first participant: the space occupied by the first participant is the second participant, hence the idea of identity ${ }^{50}$.

As for the preposition $r$ expressing future, the first participant is not yet in the second participant's space, as in the case of the hierarchical promotion, hence the future sense.

But still other meanings of these prepositions $(m$ and $r$ ) can be attributed according to their basic meanings.

${ }^{46}$ Cf. for instance, Erman, A. (1928) \445.11; Gardiner, A. H. (1957), mainly $\iint 38,44.2,116$ \& 162.6; el Din, T. Sh. (1998); Malaise, M./Winand, J. (1999) 5 514; Winand, J. (2006), 160-161.

Cf. for instance Erman, A. (1928) \446.12; Gardiner, A. H. (1957) SS 116 \& 122 , who names it " $r$ of futurity"; Malaise, M./Winand, J. (1999) \514; Winand, J. (2006), 161. In egyptological literature, it is usually translated with the future of 'be' or with expressions of the kind of 'be bound for/to'.

${ }^{48}$ In some cases, the second participant is an abstract entity with a possessive or genitive, what gives it animacy (for example, $s$ ' 'protection'). For this fact, in the context of the nominal sentence and related patterns, cf. Doret, É. (1990), Doret, É. (1991) and Doret, É. (1992).

${ }^{49}$ Lazard, G. (1994), 202-203.

${ }^{50}$ Cf. the expression of the syncretism of Re and Osiris in Litany to the Sun, wsir htp.(w) $\boldsymbol{m} r^{r} \& r^{r} p w$ htp.(w) $\boldsymbol{m}$ wsir, in Bonnet, H. (1952), 574-575; Otto, E. (1963), 269; Schenkel, W. (1974), 277; Spiegel, J. (1975), 170-174; Junge, F. (1978), 88 (\& n. 3), 91 \& 106; Hornung, E. (1992), 80 \& pl. I.

\subsubsection{Matter, partitive, company and instrument.}

The preposition $m$ expressing matter, partitive $^{51}$ and company (with animates) ${ }^{52} /$ instrument (with inanimates) constitutes an extension of the inessive, in which both participants are in the same space: there is only one entity with a part more or less abstract of itself.

Ex. 32 CT II 369 a

iw inb n.t(y) h3.s $\boldsymbol{m}$ bi3

"The wall which (is) around it (= Re's Field of Rushes) (is) of bronze".

Ex. 33 CT III 1 a

iw iš.t.i $\mathbf{m} i c b . t r h w$. wt-ntr

"My portion of meal (is) to the temples".

Ex. 34 CT IV 67 o-p

iw tn N pn $\boldsymbol{m}$ rmt htp.w-ntr $n$ N pn $\boldsymbol{m}$ hrd.w

"There is bread for this $\mathrm{N}$ with the people (and) divine offerings for $\mathrm{N}$ with the children".

Ex. 35 CT VI $52 \mathrm{f}$

mk wi $\mathrm{m}$ ir.t.i

"Here I am with my affair".

The meaning of company/instrument must be distinguished from the meaning of companionship, where the adjunct, generally animate ${ }^{53}$, displays an activity together with that of the subject, and that is expressed by the prepositionconjunction $h n^{\text {r }}$. The difference between companionship and instrument is clear, for instance, in

Ex. 36 CT II $61 \mathrm{~d}-62$ b

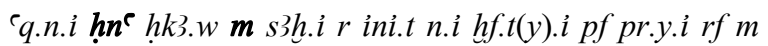
hrw

"That I have entered in the company of $h k 3 . w$ (and) with my knife, it is to bring me that enemy of mine (and) to come out then into the day".

\subsubsection{Opposition.}

Nevertheless, the use of preposition $m$ to express opposition is difficult to explain. This se-

\footnotetext{
${ }^{51}$ Cf. Winand, J. (2006), 142 (who considers the partitive an extension of the provenance SA) \& 146.

${ }^{52}$ Cf. for instance James, T. G. H. (1962), 38. The preposition $m-i^{c} b$ can also express company (CT VII 121 l). Perhaps the plurality of the entities has something to do with this use of $m$.

${ }^{53}$ Cf. Gardiner, A. H. (1957) \ 171.1.
} 
mantic extension could be complementary (without limit) of the preposition $r$ for opposition (with limit) (cf. 3.2.4), but only a systematic study could elucidate this point.

Ex. 37 CT V 333 i

imi.sn $\underline{\text { d3.sn im. } i}$

"May they not oppose (lit. against) me!"

\subsubsection{Comparison.}

The preposition $r$ expressing comparison (an extension from the adessive) presents the relationship of quality between two participants placed at different levels according to that quality.

\section{Ex. 38 CT VI 286 h}

htp.fpw m bi3 $\boldsymbol{r}$ hnmm.t

"It (means that) his (= N's) offering is (more) wonderful than hnmm. $t$ 's".

Its formal resemblance to the $r$ of future and hierarchical promotion is obvious. The use of the same morpheme for the standard of comparison and for the future is known in general linguistics ${ }^{54}$, showing the relevance of the notion of limit for these two concepts. It is absolutely crucial to distinguish the comparison of entities according to a quality (expressed by $r$ ) from the comparison according to an action (which is expressed by $m i^{55}$ and by $i s^{55}$ ) and from the direct comparison of entities (expressed by mi-qd).

Ex. 39 CT II 341 a

mk ir.t.i mi sqr pf tp.(y) iri.(w).n sth r ir.t.i

"See, my eye (is) like that first injury that Seth made against my eye".

Ex. 40 CT VI $103 \mathrm{f}-\mathrm{h}$

wnm.k d3b.k swr.k irp.k hr.k $m$ şb inpw is št. (w) im

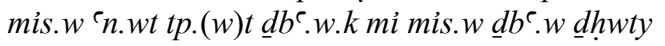

"May you eat your dates (and) drink your wine, your face (being) like a jackal's, like Anubis' masked there (and) the nail tips which (are) at your fingers (being) like Thoth's finger tips!"
Ex. 41 CT VI $286 \mathrm{q}-\mathrm{r}$

psš.tn sw šms.w nb.t k3.w.tn mspr mi-qd im.(y)w h.t

"May you share it (= N's purity), Followers of the Lady of your bull-snakes, the ribcage (being) like those who (are) in the fire!"

\subsubsection{Model.}

The preposition $r$ (and also $h f t$ ) can express the model, a very similar meaning to that of the above-mentioned comparison and that of relation (cf. 3.2.4).

\section{Ex. 42 CT IV 310 a}

iw.i $m$ šms.w $n$ nb h.wt $\boldsymbol{r} z \check{s} n$ hpr. $w^{57}$

"I (am) in the retinue of the Master of offerings, according to the writing of the Transformed".

Ex. 43 CT I 110 c-111 a iri.k tw m ntr $m$ šms.w kJ imn.t s'h.k hft s.t-ib.k

"May you make yourself as god in the entourage of the Bull of the Occident, your dignity (being) according to your desire!"

\subsubsection{Matter under discussion.}

Finally, the preposition $h r$, the most neutral of the simple spatial prepositions, is used to express, at least with certain verbs, the matter under discussion ${ }^{58}$, which originates from its essive function. Sometimes, the preposition $t p$ is used instead of $h r$ with this meaning.

Ex. 44 CT VI $207 j-m$

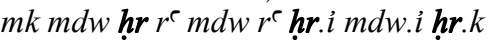

"See, the word (is) about Re, Re's word (is) about me (and) my word (is) about you (= The-one-withblack-face)".

By way of a résumé, and from a semantic point of view ${ }^{59}$, we can say that:

- the abessive case expresses a limit "by the left" (cf. 1.1), which explains the extensions of provenance (cf. 1.2), clause of anterior time (cf. 2.2) and cause (cf. 3.1);

\footnotetext{
${ }^{57}$ Main version.

${ }^{58}$ James, T. G. H. (1962), 107.

${ }^{59}$ Hagège, C. (1996), chap. 9.
} 
- the essive and inessive cases, without any expression of limit (the $\mathrm{p}_{1}$ is at or in the $\mathrm{p}_{2}$ ) (cf. 1.1), motivates the extensions of course (cf. 1.2), pseudoverbal constructions $h r / m+$ infinitive (cf. 2.1), clause of concomitant time (cf. 2.2) and characterization (cf. 3.3); and

- the adessive case, which expresses a limit "by the right" (cf. 1.1), produces the extensions of destination (cf. 1.2), pseudoverbal construction $r+$ infinitive (cf. 2.1), clause of posterior time (cf. 2.2) and finality (cf. 3.2).

All functions developed by Egyptian spatial prepositions, no matter at which syntactic level they act, show remarkable semantic stability: $m$ indicates interiority (absence of limit), $r$ exteriority (presence of limit) and $h r$ absence of the opposition interiority/exteriority. As a matter of fact, the latter preposition originally means 'on', but, relating to the other two, it has been selected to express neutrality concerning the opposition interiority/exteriority. As for the preposition $\underline{d} r$, it is only used as a conjunction, expressing limit. The prepositions $n$ and $h r$ are the equivalent, animate and animate divine respectively, of preposition $r$.

Table 4 displays the semantic functions of basic prepositions expressing space at different semantic domains: situation, motion (either position or displacement) and semantic extensions (temporal and abstract relations).

Therefore, according to their use, prepositions are defined by concepts more abstract than the spatial concepts. In fact, these abstract concepts seem to be the concepts which permit the basic (spatial) meanings to develop the semantic extensions. In other words, they are the tertium

Table 4

\begin{tabular}{|c|c|c|c|c|c|c|c|}
\hline \multirow[t]{3}{*}{ Preposition } & \multirow[t]{3}{*}{ Basic notion } & \multirow{3}{*}{$\begin{array}{l}\text { Situation } \\
\text { (Adverbial } \\
\text { sentence) }\end{array}$} & \multirow{3}{*}{$\begin{array}{l}\text { Motion } \\
\text { (Verbal } \\
\text { sentence) }\end{array}$} & \multicolumn{4}{|c|}{ Semantic extensions } \\
\hline & & & & \multirow[t]{2}{*}{ Temporal } & \multicolumn{3}{|c|}{ Abstract relations } \\
\hline & & & & & Cause & Finality & Characterization \\
\hline$h r$ & $\begin{array}{l}\text { Generality } \\
\text { (absence of } \\
\text { mark) }\end{array}$ & general & general & $h r+$ infinitive & $\begin{array}{l}\text { Causal } \\
\text { adjunct \& } \\
\text { clause }\end{array}$ & - & $\begin{array}{l}\text { Matter under discus- } \\
\text { sion (also } t p \text { ) }\end{array}$ \\
\hline$m$ & $\begin{array}{l}\text { Unity (absence } \\
\text { of orientation } \\
\text { and limit) }\end{array}$ & interior & interior & $\begin{array}{l}m+\text { infinitive } \\
\text { Concomitant } \\
\text { clause }\end{array}$ & $\begin{array}{l}\text { Causal } \\
\text { adjunct \& } \\
\text { clause }\end{array}$ & - & $\begin{array}{l}\text { Attribution of function } \\
\text { Identity } \\
\text { Matter } \\
\text { Partitive } \\
\text { Company/instrument } \\
\text { Opposition } \\
\end{array}$ \\
\hline$r$ & $\begin{array}{l}\text { Facing } \\
\text { (orientation } \\
\text { mainly towards } \\
\text { the "right" } \\
\text { and separation } \\
\text { from a limit) }\end{array}$ & exterior & exterior & $\begin{array}{l}r+\text { infinitive } \\
\text { Clause of } \\
\text { posterior } \\
\text { time }\end{array}$ & - & $\begin{array}{l}\text { Implicative } \\
\text { Final clause } \\
\text { Opposition } \\
\text { Relation } \\
\text { Condition }\end{array}$ & $\begin{array}{l}\text { Attribution of function } \\
\text { Future/intention/ } \\
\text { destiny } \\
\text { Comparison } \\
\text { Model (also } h f t \text { ) }\end{array}$ \\
\hline$n$ & $\begin{array}{l}\text { Facing }+ \\
\text { animacy }\end{array}$ & exterior & exterior & - & $\begin{array}{l}\text { Causal } \\
\text { adjunct \& } \\
\text { clause } \\
\text { Agent (in) } \\
\text { Cleft sent- } \\
\text { ence (in) }\end{array}$ & $\begin{array}{l}\text { Implicative } \\
\text { Beneficiary } \\
\text { Possession } \\
\text { Final adjunct } \\
\text { \& clause }\end{array}$ & - \\
\hline$h r$ & $\begin{array}{l}\text { Facing }+ \\
\text { divinity }\end{array}$ & exterior & exterior & - & Divine agent & - & - \\
\hline$\underline{d} r$ & $\begin{array}{l}\text { Limit } \\
\text { (separation } \\
\text { from a limit } \\
\text { and absence } \\
\text { of orientation) }\end{array}$ & - & - & $\begin{array}{l}\text { Clauses of } \\
\text { anterior \& } \\
\text { posterior } \\
\text { time }\end{array}$ & $\begin{array}{l}\text { Causal } \\
\text { adjunct \& } \\
\text { clause }\end{array}$ & - & - \\
\hline
\end{tabular}


comparationis or the family resemblance ${ }^{60}$ for each preposition. Definitions proposed for these prepositions are as follows: $h r$ expresses generality, $m$ unity, $r$ facing, $n$ animate facing, $h r$ divine facing and $\underline{d} r$ limit.

\section{References}

Anderson, J. M. (1976): The grammar of case. Towards a localistic theory. Cambridge: Cambridge University Press.

Berthonneau, A. M. (1993): "Avant/après: de l'espace au temps", in Berthonneau, A. M./ Cadiot, P. (eds.): Les prépositions: méthodes d'analyse (Lexique 11). Lille: Presses Universitaires de Lille, 41-110.

Bertinetto, P. M. (1997): Il dominio tempo-aspettuale: demarcazioni, sezioni, contrasti. Torino: Rosenberg \& Sellier.

Bonnet, H. (1952): Lexikon der ägyptischen Religionsgeschichte. Berlin: Walter de Gruyter \& Co. (reprint 2001).

Carrier, C. (2004): Textes des sarcophages du Moyen-Empire égyptien, I-III. Paris: du Rocher.

Collier, M. (1994): "Grounding, cognition and metaphor in the grammar of Middle Egyptian", in Junge, F./Kammerzell, F./Loprieno, A. (eds.): Proceedings of the International Conference on Egyptian grammar (Crossroads III). Yale, april 4-9, 1994 (Lingua Aegyptia 4). Göttingen: Seminar für Ägyptologie und Koptologie, 57-87.

$\mathrm{CT}=$ De Buck, A.: The Egyptian Coffin Texts, I-VII (Oriental Institute Publications 24, 49, 64, 67, 73, 81 \& 87). Chicago: University of Chicago Press, 1935-1961.

D’Aquili, E.G. (1983): "The myth-ritual complex: a biogenetic structural analysis", Zygon 18, $247-$ 269.

Delancey, S. (1982): “Aspect, transitivity and viewpoint”, in Hopper, P. J. (ed.): Tense-aspect: between semantics and pragmatics. Containing the contributions to a symposium on tense and aspect, held at UCLA, May 1979 (Typological Studies in Language 1). Amsterdam/Philadelphia: Benjamins, 167-183.

Depuydt, L. (1998): "Events engaged in the grammatical tango of contiguity: the case of the preposition $\underline{d} r$ ", Journal of the American Research Center in Egypt 35, 73-88.

el Din, T. Sh. (1998): "Notes on the so-called $m$ of predication", Discussions in Egyptology 42, $15-24$.

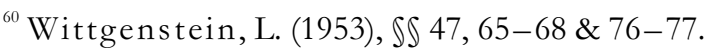

Doret, É. (1990): "Phrase nominale, identité et substitution dans les CT ( $2^{\mathrm{e}}$ partie)", Revue d'Egyptologie 41, 39-56.

Doret, É. (1991): “Cleft-sentence, substitutions et contraintes sémantiques en égyptien de la première phase (V-XVIII dynastie)", in Loprieno, A. (ed.): Proceedings of the Second International Conference on Egyptian Grammar (Crossroads II). Los Angeles, october 17-20, 1990 (Lingua Aegyptia 1). Göttingen: Seminar für Ägyptologie und Koptologie, 57-96.

Doret, É. (1992): "Phrase nominale, identité et substitution dans les Textes des Sarcophages $\left(3^{\mathrm{e}}\right.$ partie)", Revue d'Egyptologie 43, 49-73.

Edel, E. (1954-1964): Altägyptische Grammatik, I-II (Analecta Orientalia 34 \& 39). Roma: Pontificium Institutum Biblicum.

Erman, A. (1928): Ägyptische Grammatik (Porta Linguarum Orientalium 15). Berlin: Von Reuther $\&$ Reichard. (4 $4^{\text {th }}$ ed.).

Faulkner, R. O. (1994-1996): The ancient Egyptian Coffin Texts, I-III. Warminster: Aris \& Phillips Ltd. (1994: reprint I-II; 1996: reprint III).

Fillmore, Ch. J. (1975): Santa Cruz lectures on deixis, 1971. Bloomington: Indiana University Linguistics Club.

Gardiner, A. H. (1957): Egyptian grammar. Being an introduction to the study of hieroglyphs. Oxford/London: Griffith Institute/Oxford University Press.

Gattis, M. (2001) (ed.): Spatial schemas and abstract thought. Cambridge (Massachusetts): MIT.

Golénischeff, W. (1913): Les papyrus hiératiques nos. 1115, 1116 A et 1116 B de l'Ermitage impérial à St. Petersbourg. San Petersbourg.

Gracia Zamacona, C. (2008): Les verbes de mouvement dans les Textes des Sarcophages: étude sémantique. PhD dissertation. Ecole Pratique des Hautes Etudes (Paris).

Hagège, C. (1996): L'homme de paroles. Contribution linguistique aux sciences humaines. Paris: Fayard.

Hagège, C. (1999): “Théorie linguistique”, Annuaire du Collège de France, 1998-1999, 773-776.

Haspelmath, M. (1997): From space to time. Temporal adverbials in the world's languages (LINCOM studies in theoretical linguistics 3). München/Newcastle: LINCOM Europa.

Hjelmslev, L. (1935 \& 1937): La catégorie des cas (Acta Jutlandica 7 \& 9). Copenhagen: Munsksgaard.

Hornung, E. (1992): Les dieux de l'Egypte. Paris: Flammarion. $\left(1^{\text {st }}\right.$ ed. 1971$)$.

James, T. G. H. (1962): The Hekanakhte papers and other early Middle Kingdom documents. Oxford: University Press of Oxford.

Junge, F. (1970): Studien zum mittelägyptischen Verbum. Göttingen, 1970. 
Junge, F. (1978): "Wirklichkeit und Abbild. Zum innerägyptischen Synkretismus und zur Weltsicht der Hymnen des Neuen Reiches", in Wiessner, G. (ed.): Synkretismusforschung. Theorie und Praxis (Göttinger Orientforschungen, Grundlagen und Ergebnisse 1). Wiesbaden: Harrassowitz, 87108.

Junge, F. (1996): Neuägyptisch. Einführung in die Grammatik. Wiesbaden: Harrassowitz.

Kimball, J. (1974): The grammar of facing. Bloomington: Indiana University Linguistics Club.

Kleiber, G. (1990): La sémantique du prototype. Catégories et sens lexical. Paris: Presses Universitaires de France.

Klein, W. (1994): Time in language. London/New York: Routledge.

Lakoff, G./Johnson, M. (1980): Metaphors we live by. Chicago: Chicago University Press.

Lamiroy, B. (1988): "Les verbes de mouvement, emplois figurés et extensions métaphoriques", in Vandeloise, C. (ed.): L'expression du mouvement (Langue Française 76). Paris: Larousse, $41-$ 58.

Langacker, R. W. (1987): Foundations of cognitive grammar, I: Theoretical prerequisites. Stanford: Stanford University Press.

Lazard, G. (1994): L'actance. Paris: Presses Universitaires de France.

Loprieno, A. (1986): Das Verbalsystem im Ägyptischen und im Semitischen. Zur Grundlegung einer Aspekttheorie (Göttinger Orientforschungen IV/17). Wiesbaden: Harrassowitz.

Loprieno, A. (1988): "Der ägyptische Satz zwischen Semantik und Pragmatik: die Rolle von jn", in Schoske, S. (ed.): Akten des vierten internationalen Ägyptologen Kongresses. München 1985, I-IV. Hamburg: Buske, III, 77-98.

Loprieno, A. (1995): Ancient Egyptian. A linguistic introduction. Cambridge: Cambridge University Press.

Lyons, J. (1994): Introduction to theoretical linguistics. Cambridge: Cambridge University Press. ( $1^{\text {st }}$ ed.: 1969$)$.

Malaise, M./Winand, J. (1999): Grammaire raisonnée de l'égyptien classique (Aegyptiaca Leodiensia 6). Liège: Centre Informatique de Philosophie et Lettres.

Naïm, S. (2006) (ed.): La rencontre du temps et de l'espace. Approches linguistique et anthropologique (Société d'Etudes Linguistiques et Anthropologiques de France 433; numéros spéciaux, 32). Leuven: Peeters.

Otto, E. (1963): “Altägyptischer Polytheismus. Eine Beschreibung", Saeculum 14, 249-258.

Posener, G. (1956): Littérature et politique dans l'Egypte de la XII ${ }^{\mathrm{e}}$ dynastie (Bibliothèque de l'Ecole des Hautes Etudes, Sciences Historiques et Philologiques 307). Paris: Champion.
Pottier, B. (1962): Systématique des éléments de relation. Etude de syntaxe structurelle romane. Paris: Klincksieck.

Reintges, Ch. (1998): "Mapping information structure to syntactic structure: one syntax for $j n$ ", Revue d'Egyptologie 49, 195-220.

Rojas Nieto, C. (1988): Verbos locativos en español (Publicaciones del Centro de Lingüística Hispánica 29). México: Universidad Nacional Autónoma de México, Instituto de Investigaciones Filológicas.

Savary, R. (1984): Ordre langagier, champ spatial et emplois "figurés". Tübingen: Niemeyer.

Schenkel, W. (1974): "Amun-Re", Studien zur Altägyptische Kultur 1, 275-288.

Spiegel, J. (1975): "Versuche zur Verschmelzung von Rê und Osiris", in Westendorf, W. (ed.): Göttinger Totenbuchstudien. Beiträge zum 17. Kapitel (Göttinger Orientforschungen IV/3). Wiesbaden: Harrassowitz, 129-181.

Svorou, S. (1994): The grammar of space (Typological Studies in Language 25). Amsterdam: Benjamins.

Traugott, E. C. (1978): "On the expression of spatio-temporal relations in language", in Greenberg, J.H. et al.: Universals of human language, III: Word structure. Stanford: Stanford University Press, 369-400.

Traugott, E. C./König, E. (1991): “The semantics-pragmatics of grammaticalization revisited", in Traugott, E. C./Heine, B. (eds.): Approaches to grammaticalization, I-II. Amsterdam/ Philadelphia: Benjamins, I, 189-218.

Vandeloise, C. (1988): "La préposition à et le principe d'anticipation", in V andeloise, C. (ed.): L'expression du mouvement (Langue Française 76). Paris: Larousse, $77-111$.

Vernus, P. (1987): "Etudes de philologie et de linguistique (VI)", Revue d'Egyptologie 38, 163 181.

Vernus, P. (1989): "Derechef mi régissant une forme à suffixe - $t$ ', Revue d'Egyptologie 40, 199-200.

Vernus, P. (1990): Future at issue. Tense, mood and aspect in Middle Egyptian: studies in syntax and semantics (Yale Egyptological Studies 4). New Haven: Yale Egyptological Seminar.

Vernus, P. (1996): "La grammaticalisation en égyptien ancien: phrase nominale et morphogenèse de l'inaccompli et du futur", Mémoires de la Société de Linguistique de Paris (N.S.) V, 63-83.

Vernus, P. (1997): Les parties du discours en moyen égyptien. Autopsie d'une théorie (Cahiers de la Société d'Egyptologie 5). Genève: Société d'Egyptologie de Genève.

Vernus, P. (1999): "Une formulation de l'autobiographie et les expressions avec $w n$ et $m 3^{\text {e", }}$ Göttinger Miszellen 170, 101-105. 
$\mathrm{Wb}=$ Erman, A./Grapow, H.: Wörterbuch der ägyptischen Sprache, I-VII. Leipzig: Hinrichs, 1926-1963.

Winand, J. (2006): Temps et aspect en égyptien. Une approche sémantique (Probleme der Ägyptologie 25). Leiden: Brill.

Wittgenstein, L. (1953): Philosophical investigations. London: Blackwell.

\section{Summary}

This paper briefly proposes a semantic approach to a cross-linguistically well known phenomenon: the use of the expression of space-situation or motionto express temporal and abstract relations-cause, characterization and finality. The study is the result of a thoroughly analysis of data from the Coffin Texts.

\section{Keywords}

Coffin Texts - Space - Semantic extension Preposition - Linguistics, Ancient Egyptian 